\title{
Dev Sürrenal Kitle
}

\section{Giant Surrenal Mass}

Serhat Doğan ${ }^{1}$,

Adil Kartal ${ }^{2}$,

Tevfik Küçükkartallar ${ }^{3}$,

Mustafa Şentürk ${ }^{3}$,

Yusuf Yavuz ${ }^{3}$,

Mehmet Aykut Yıldırım

${ }^{1}$ Malatya Eğitim ve Araştırma Hastanes

Genel Cerrahi Kliniği, Malatya, Türkiye

${ }^{2}$ Eğitim ve Araştırma Hastanesi, Genel

Cerrahi Kliniği, Konya Türkiye

${ }^{3}$ Necmettin Erbakan Üniversitesi Meram

Tıp Fakültesi Genel cerrahi Anabilim Dalı,

Konya, Türkiye.

Geliş Tarihi/Received: 2 Kasım 2017

Kabul Tarihi/Accepted: 30 Mayıs 2018

Yazışma Adresi: Serhat Doğan,

Malatya Eğitim ve Araştırma Hastanesi Genel

Cerrahi Kliniği, Malatya, Türkiye

e-posta: drserhatdogan@gmail.com

\section{ORCID}

Serhat Doğan

https://orcid.org/0000-0002-3288-2963

\section{GiRiş}

Obezite, hipertansiyongibipotansiyelolarakadrenal bezlerle ilgili olabilecek bir hastalık araştırılırken veya tamamen tesadüfen tespit edilen sürrenal tümörler insidentaloma başlığı altında incelenir. Nonfonksiyonel sürrenal tümörlere insidentaloma veya adrenaloma denir. Her ne kadar bu hastalar daha sonra retrospektif olarak değerlendirildiğinde sürrenal kitle ile ilgili veya hormonal açıdan aktif olmalarına bağlı şikayetlere sahip oldukları tespit edilsede, tesadüfi tespit edilmiş olmaları insidentaloma gurubunda değerlendirilmelerini uygun hale getirmiştir (1).

Son yıllarda özellikle manyetik rezonans görüntüleme (MRG), bilgisayarlı tomografi (BT) ve ultrasonografinin (USG) yaygın kullanımı ile birlikte insidentalomaların genel insidansında belirgin bir artış saptanmıştır (2). Renal hücreli karsinom (RHK), böbrek korteksinden kaynaklanır. Tüm kanserlerin \%2'sini ve böbrek malignitelerinin \%80-85'ini oluşturur (7). RHK, böbrek tübül epitelinden kaynaklanan malignite grubudur (8). Tanısı ortalama $55-60$ yaşları arasında konulan, genellikle yetişkinlerde görülen bir tümördür. Rölatif olarak nadir bir tümör olup her 100.000 insandan 6'sı hastalıktan etkilenir. İnsidansı giderek artmaktadır. Erkekler kadınlara göre daha sık (E/K: 2/1) etkilenir (9-11)

Bizim ilk olgumuzda radyoloji tarafından karaciğer hemanjiomu olarak tarif edilen olgunun aslında sağ sürrenalden kaynaklanan adenom olduğunu gördük. İkinci vakamızda da yine karaciğer hemanjiomu olarak tarif edilen kitlenin sağ böbrekten kaynaklanan renal hücreli karsinom olduğu gördük. Ameliyat hazırlıklarında radyolojik verilerin ne kadar önemli bir şekilde değerlendirilmesi gerektiğini bir kez daha anladık.

\section{OLGU}

Kırk bir yaşında kadın hasta karın ağrısı şikayeti ile başvurdu. Hastanın herhangi bir yandaş hastalığı yoktu. Karın ağrısı için çeşitli tetkikler istedi. Hastanın yapılan tetkiklerinde Beyaz küre: 8,3 /ul, Hemoglobin: 13,7 gr/dl, Trombosit: 382000 /uL, Sedimentasyon 
60mm/h, AST:15 u/L, ALT $12 \mathrm{u} / \mathrm{L}$ di. Diğer kan tahlillerinin hepsi normaldi.

Batın usg sinde karaciğerden kayanaklanan yaklaşık 12x10 cm lik lezyon tarif edildi. Bunun üzerine hastaya dinamik karaciğer BT çekildi. "Karaciğer parankimi içerisinde sağ lob posterior segmenti dolduran yaklaşık 110x107 mm boyutlarında periferden boyanan hemanjiom açısından şüpheli lezyon izlenmiştir. Lezyonun santralinde kalsifikasyonlar dikkati çekti. Hepatoselüler karsinom? hemanjiom?" şeklinde yorumlandı. Hepatosellüler Karsinom şüphesi nedeniyle hastadan Usg yardımıyla biyopsi alındı. Patoloji sonucu nekroz ve kanama olarak rapor edildi.

Bunun üzerine hasta ameliyat için hazırlıklara başlandı. Hasta operasyona alındı. Operasyon sırasında kitlenin karaciğerden değilde sağ surrenalden kaynaklandığı görüldü. Yaklaşık $13 \times 15 \times 17 \mathrm{~cm}$ lik kitle vardı. Medialde vena cava ile komşuydu. Keskin diseksiyonla ayrıldı ve bir bütün halinde çıkartıldı. Bir adet dren yerleştirilerek işleme son verildi. Operasyon sonrası hasta yoğun bakım ünitesine alındı. Hastanın operasyon sonrası vitalleri stabil seyretti. Hasta bir gün sonra yoğun bakımdan servise devredildi. Hasta operasyon sonrası üçüncü gün dreni çekilerek, önerilerle taburcu edildi. İkinci olgumuz 64 yaşında erkek hasta karın ağrısı şikayeti ile başvurdu. Hastanın herhangi bir yandaş hastalığı yoktu. Karın ağrısı için çeşitli tetkikler istedi. Hastanın yapılan tetkiklerinde Beyaz küre : 10,3 / ul, Hemoglobin:14,6 gr/dl, Trombosit: 481000 /uL, Sedimentasyon 20mm/h, AST:19 u/L, ALT $25 \mathrm{u} / \mathrm{L}$ di. Diğer kan tahlillerinin hepsi normaldi. Çekilen dinamik karaciğer BT sinde "Karaciğer parankimi içerisinde sağ lob posterior segmenti dolduran yaklaşık $25 \times 25 \mathrm{~cm}$ boyutlarında periferden boyanan hemanjiom açısından şüpheli lezyon izlenmiştir. Lezyonun santralinde kalsifikasyonlar dikkati çekti. Hepatoselüler karsinom ? hemanjiom ?" şeklinde yorumlandı. Hepatosellüler Karsinom şüphesi nedeniyle hastadan Usg yardımıyla biyopsi alındı. Patoloji hepatoselüler karsinom olarak rapor edildi.

Hastanın operasyonunda kitlenin sağ böbrekten kaynaklandığı görüldü. Nefrektomi yapıldı. Bir adet diren koanrak işleme son verildi. Hasta ameliyat sonrası yoğun bakım ünitesine alındı. Post operatif 2 . gün servise çıkarıldı. Direni çekilerek taburcu edildi.

\section{TARTIŞMA}

Sürrenal adenomlar,üst abdomen bölgesinin çeşitli nedenlerle incelenmesi sonucu insidental
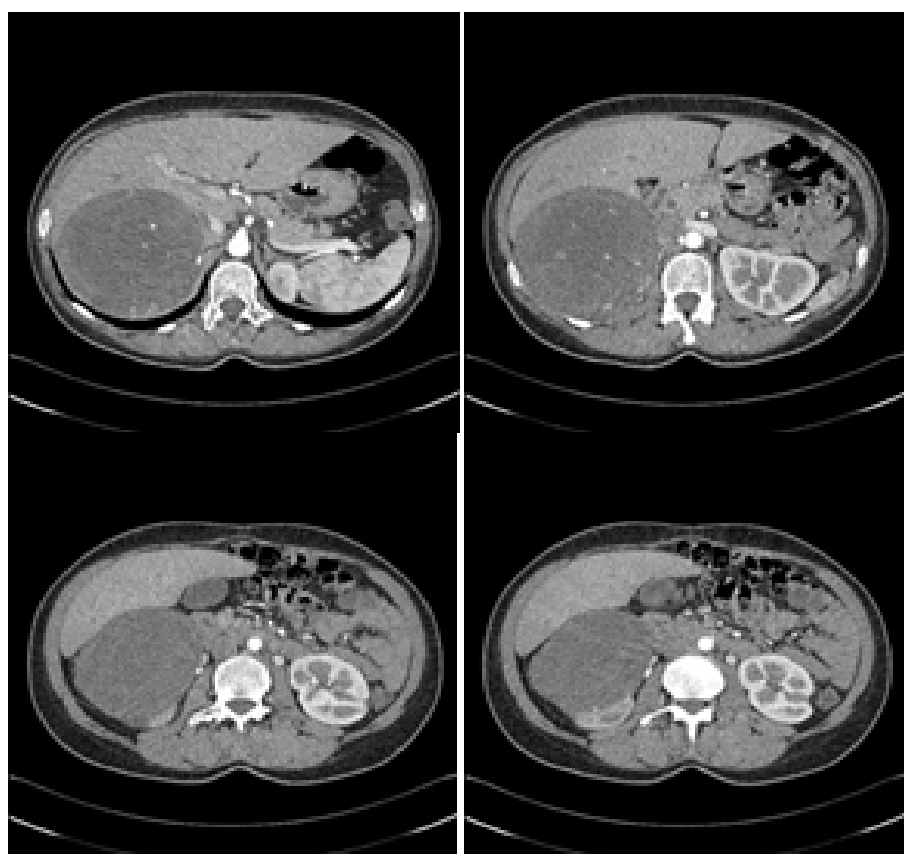

Şekil 1. İlk olgumuz dinamik karaciğer BT görüntüleri (sürrenal adenom) (41 y K)

olarak saptanan bu kitlelerin çoğu benign lezyonlar olup genellikle nonsekretuvar kortikal kitledirler. Radyolojik incelemeler sonucunda rastlantısal olarak saptanırlar. Görülme insidansları \% 1.4 - 8.7

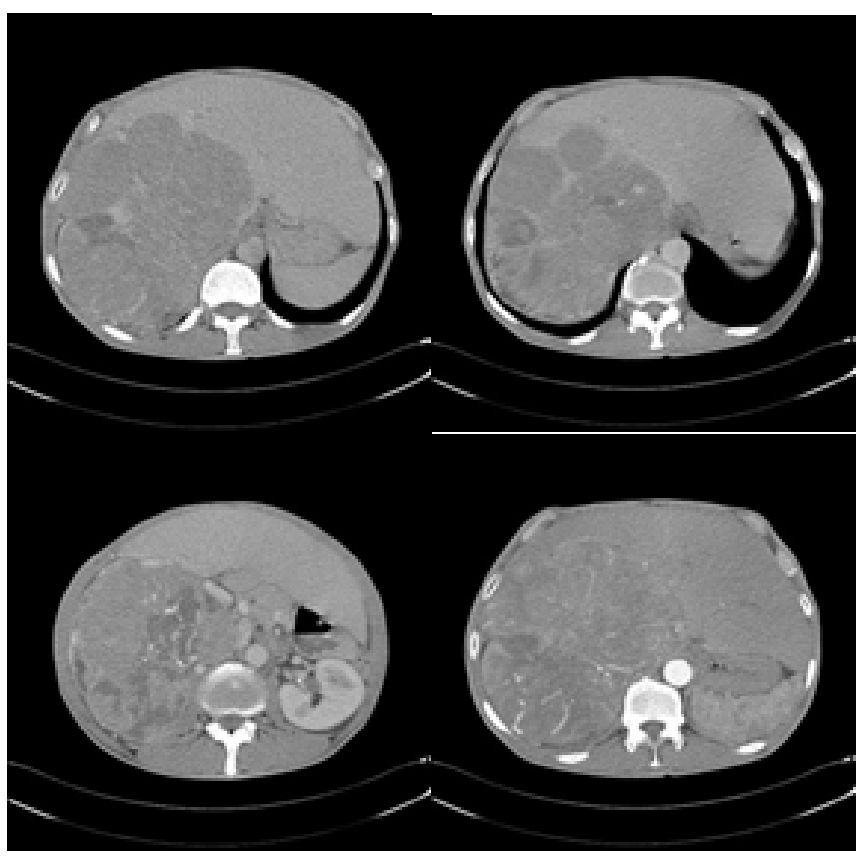

Şekil 2. Íkici olgumuzun dinamik karaciğer BT si (sağ renal hücreli karsinom) (64 y E) 


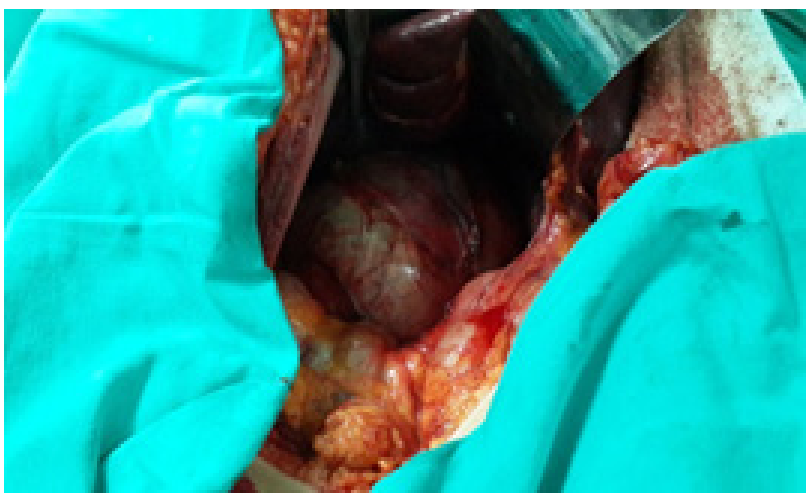

Şekil 3. Operasyon anında çekilmiş bir fotoğraf

arasında değişmektedir. Adrenal kitlelerinin \% 94'ü benign, \% 90'ı nonfonksiyone olup \% 80 kadarının çapı 2 cm'den küçüktür. Malign adrenal kitlelerin görülme oranı daha düşük olup bu kitlelerin çapları genellikle 5 cm'nin üzerindedir (3). Görüntüleme ve laboratuar yöntemlerindeki gelişmeler ve bu yöntemlerin giderek yaygınlaşması ile sürrenal kitlelerin saptanması kolaylaşmıştır. Sürrenal kitlelerin görülme insidansı geniş otopsi serilerinde \%3-5; Batın BT görüntülemelerinde $\%$ 0.5-10 olarak bulunmuştur (4). Linos et al. (5) cerrahi tekniğin ilerlemesi ile sürrenalektomi morbidite ve mortalitesinin çok azaldığını, çok küçük kitlelerde bile malignite olasılığı olduğunu ve nonfonksiyone kitlelerin zamanla fonksiyon kazanabileceğini, bunların takiplerinde yapılacak tetkik ve BT maliyetinin sürrenalektomiden daha yüksek olacağını öne sürerek tespit edilen her sürrenal kitlenin çıkarılmasını tavsiye etmişlerdir. İlk Olgumuzun dinamik karaciğer BT si radyologlar tarafından raporlandı (Şekil 1).

Cerrahi prosedürlerin seçiminde sürrenal

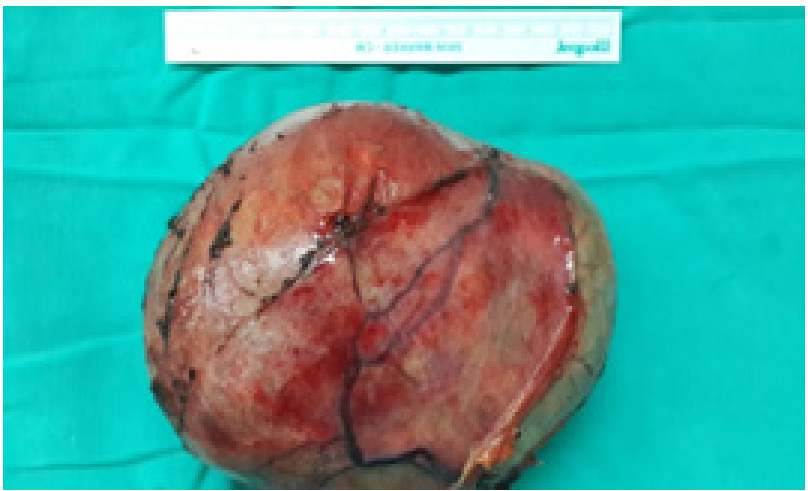

Şekil 4. Piyesin çıkarılmış hali( olgu 1)

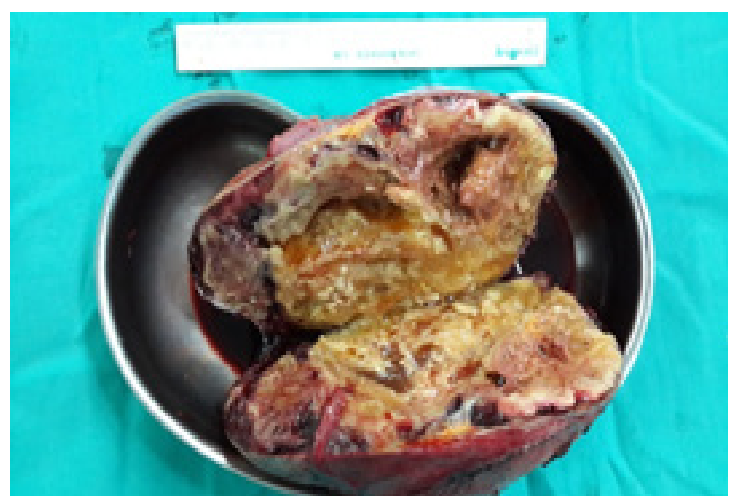

Şekil 5. Piyesin ortadan kesildiğindeki görünümü

patolojiye yol açan neden, bezin büyüklüğü, lezyonun büyüklüğü, hastanın fiziksel konumu ve cerrahın deneyimi önemlidir. Olgumuzda transperitoneal yaklaşım kullanılmıştır. Hastaya sağ sağ hockey stick kesi ile operasyona başlanmıştır. Transperitoneal yaklaşımımızdaki amacımız karaciğerdeki hemanjiomun operasyonu için daha geniş bir ekplorasyon alanı sağlamaktı. Laparoskopik sürrenalektomi benign adrenal kitlelerin tedavisinde altın standart tedavi halini almıştır. Günümüzde 4 cm'den çok daha büyük primer benign ve malign kitlelere de deneyimli ellerde laparoskopik sürrenalektomi uygulanabilmektedir (6). Olgumuzda kitlenin hem büyük olması hem de karaciğer kaynaklı olduğunu düşündüğümüz için laparoskopik prosedürü düşünmedik. Operasyondan foroğraflar ve piyesin görünümü (Şekil 2-5 ). İkinci olgumuzun dinamik karaciğer BT si radyologlar tarafından yorumlandı.

Renal hücreli kanser etyolojisinde değişik faktörler rol almakla birlikte kesin bir neden gösterilememiştir. Sigara içimi, obezite, mesleki faktörler (asbest,

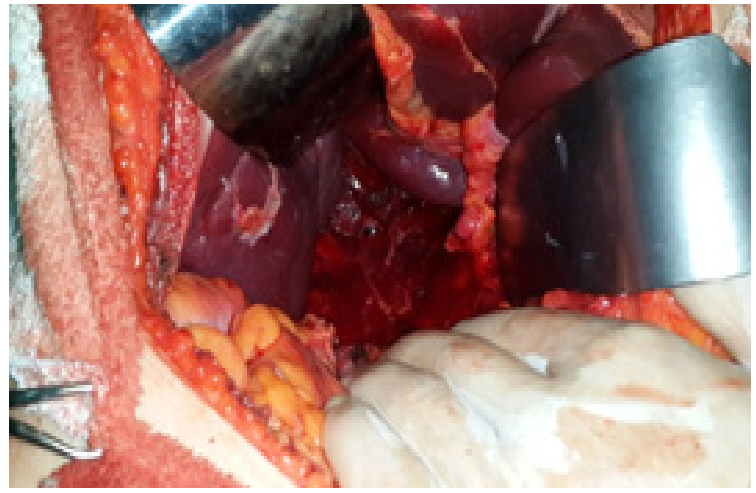

Şekil 6. Operasyon sonrası görüntüsü 
kadmiyum, petrol ürünleri) herpes virus infeksiyonları, son dönem böbrek yetmezliği hastalığın insidansını arttırmaktadır. Genetik nedenler arasında 3. ve 11. kromozomlar sorumlu tutulmaktadır (8). RHK böbreklerin retroperitoneal yerleşimi nedeniyle sıklıkla hastalığın doğal seyrinin ileri dönemlerine kadar palpe edilemez ve asemptomatik kalır (12). Olgumuzda açık prosedürü tercih ettik.

\section{SONUÇ}

Karaciğer hemanjiomları ile surrenal bölgedeki kitlelerin karşıbileceğini hatırlatmak istiyoruz. Kliniğimizde 5 yıl ara ile karşımıza çıkan iki olguyu paylaşmakistedik.Operasyonhazırlıklarındaradyolojik verilerin çok titiz şekilde değerlendirilmelidir. Her vaka kendi açısından değerlendirilmelidir. Radyolojik veriler her zaman doğru olmayabilir. Operasyon esnasında bu gibi durumlarda karşılaşıldığında cerrahın her zaman için bir b planı olmalıdır.

Çıkar Çatışması: Çalışmada herhangi bir çıkar çatışması yoktur.

Finansal Çıkar Çatışması: Çalışmada herhangi bir finansal çıkar çatışması yoktur.

Yazışma Adresi: Serhat Doğan, Malatya Eğitim ve Araştırma Hastanesi Genel Cerrahi Kliniği Malatya, Türkiye

e-posta: drserhatdogan@gmail.com

\section{KAYNAKLAR}

1. Minowada S, Fujimura T, Takahasi N, et al. Computed tomography guided percutaneous acetic asid injection therapy for functioning adrenocortical adenoma. J Clin Endocrinol Metab 2003;88:5814-7.
2. Nader HN, Daniel KE. Advances in the management of adrenal tumors. Current Opinion in Oncology 2000;11:49-53.

3. Dr. Ercan Kocakoç Adrenal lezyonlarda MR, Ders notları. Bezmialem Vakıf Üniversitesi Tıp Fakültesi Radyoloji Anabilim Dalı İstanbul 2014.1-54.

4. Adler JT, Meyer - Rochow GY, Chen $\mathrm{H}$, et al. Pheochromocytoma: Current approaches and future directions. The Oncologist 2008;13:779.

5. Linos D A, Stylopoulos N, Raptis S A, Adrenaloma: A call for more aggressive management. World J Surg 1996;20:78893.

6. Erbil Y, Barbaros U, Aral F et al. Transabdominal laparoscopic adrenalectomy: Our clinical experience in 62 procedures. Endokrinolojide Diyalog 2008;4:181-7.

7. Kosary CL, McLaughlin JK. Kidney and renal pelvis. In: Miller BA, Ries LAG, Hankey BF, eds. SEER cancer statistics review, 1973-1990. Bethesda: National Cancer Institute, 1993.

8. Eble JN, Togashi K, Pisani P. Renal cell carcinoma. In: Eble JN, Sauter G, Epstein JI, eds. World health organization classification of tumours. Pathology and genetics of tumours of the urinary system and male genital organs. IARC Press; 2004:9-87.

9. Murphy WM, Beckwith JC, Farrow GM. Normal anatomy. In: Rosai J, Sobin LH, eds. Tumors of the kidney, bladder and related urinary structures. AFIP;1994:1-11.

10. Ordonez NG, Rosai J. Renal cell carcinoma. In: Rosai J, ed. Surgical pathology, Mosby; 2004:1251-63.

11. Eble JN. Renal neoplasia. In: Weidner N, Cote RJ, Suster S, eds. Modern surgical pathology. Saunders; 2003:1065-101.

12. Novick AC, Campbell SC. Renal tumors. In: Walsh PC, Retik AB, Vaughan ED, eds. Campbell's urology. Philadelphia: WB Saunders, 2002;2672-731. 